\title{
Prinsip-Prinsip dan Efektivitas Desentralisasi Pendidikan Dalam Rangka Meningkatkan Mutu dan Relevansi Pendidikan
}

\author{
Subijanto \\ Bagian Perencanaan Sekretariat Balitbang Kemendiknas
}

\begin{abstract}
Abstrak: Desentralisasi pendidikan yang efektif tidak hanya melibatkan proses pemberian kewenangan dan pendanaan yang lebih besar dari Pemerintah Pusat ke pemerintah daerah, tetapi desentralisasi harus menyentuh pemberian kewenangan yang lebih besar ke sekolah dalam menentukan berbagai kebijakan, seperti organisasi dan proses belajar-mengajar, manajemen guru, struktur dan perencanaan di tingkat sekolah, dan sumber pendanaan sekolah. Undang-Undang Nomor 20/2003 tentang Sisdiknas mendukung dengan memberikan kewenangan otonomi pendidikan langsung kepada setiap satuan pendidikan melalui manajemen berbasis sekolah. Mutu dan relevansi pendidikan ada pada setiap proses pentahapan pada satuan pendidikan. Komitmen Pemerintah untuk berinvestasi pada pendidikan sebagai solusi masa depan bangsa harus segera diwujudkan melalui pengalokasian $20 \%$ APBN untuk pendidikan di luar anggaran pendidikan kedinasan dan gaji guru. Untuk memperkuat dukungan pengembangan pendidikan, diperlukan kemitraan yang erat antara pemerintah, pemerintah daerah, dan masyarakat dalam menyelenggarakan pendidikan yang bermutu. Untuk meningkatkan daya saing bangsa, pendidikan unggulan bertaraf internasional perlu dikembangkan, dimonitor, dan dievaluasi secara bertahap dan berkesinambungan di setiap daerah dengan menekankan relevansi dengan kebutuhan, ciri khas daerah/ keunggulan lokal.
\end{abstract}

Kata kunci: desentralisasi pendidikan, mutu dan relevansi pendidikan

\begin{abstract}
Abstrack: The effectiveness of decentralization is not only giving involving authority process and budget from central government to local government but also giving authority as a whole to the school through holistic authority in defining policy of education, such as: teaching-learning process organization, management of teacher, structur and school planning, and school budget resources. The Act number 20 of the year 2003 about National Education System was support the authority education budget directly to every school through school based management. The quality and relevance of education in each stage of education had been stated. Therefore, the Government was commited to invest for education as a solution of nation in the future that is through $20 \%$ Fiscal National Budget for education could be operationalized excluded government education dan salary of teacher. For empowering support development of education the government shoud be collaboration with local government, society, and private company in conducting the quality of education. To increase the nation of competitiveness, the quality of education which is equal to the international standard need to be developed, to be monitor, and to be evaluate stages by stages and continuously in every region with more emphasises on relevancy based on demand, the characteristic of local region and prominence to local content based education.
\end{abstract}

Key words: educational decentralization, quality and relevancy of education

\section{Pendahuluan}

Isu manajemen strategis pendidikan dalam rangka meningkatkan mutu dan keunggulan daya saing bangsa sangat diperlukan dengan pertimbangan sangat mendasar, yaitu cita-cita mulia kemerdekaan Indonesia untuk mencerdaskan kehidupan bangsa (Pembukaan UUD, 1945). Hal ini dikandung maksud agar bangsa Indonesia terbebas dari belenggu kebodohan, kemiskinan dan ketidak- adilan. Fakta menunjukkan bahwa meskipun tingkat melek huruf di Indonesia telah cukup tinggi, namun jumlah penduduk yang telah menyelesaikan pendidikan di atas sekolah dasar masih rendah. Rendahnya tingkat pendidikan bangsa Indonesia tercermin antara lain dari Indeks Hasil Pembangunan Manusia (Human Development Index) tahun 2008 di mana Indonesia berada pada peringkat ke 109 dari 179 negara (nilai 
$0,726)$, peringkat tersebut terendah di Asia Tenggara (HDI update 2008 Indonesia, diakses melalui Google tanggal 20 Agustus 2010).

Lebih lanjut, laporan Mendiknas (saat itu Malik Fajar) tanggal 31 Januari 2002 menyatakan bahwa tidak semua lulusan SMP dan SMA melanjutkan pendidikan ke jenjang yang lebih tinggi. Hal ini didukung oleh data Balitbang Depdiknas tahun 2000 yang menyatakan bahwa $88,4 \%$ Iulusan SMA tidak melanjutkan ke perguruan tinggi, sedangkan $34,4 \%$ SMP lulusan tidak melanjutkan ke sekolah menengah. Di samping itu, sekitar $63,35 \%$ struktur tenaga kerja Indonesia berpendidikan SD dan secara keseluruhan kualitas sumber daya manusia (SDM) masih tergolong rendah (Siswo Wiratno, 2009). Salah satu indikator bahwa kualitas SDM Idonesia rendah tercermin pada data yang menunjukkan bahwa 78,8 \% tidak tamat sekolah dasar (SD), $10,72 \%$ tamat SMP dan 10,69 \% tamat SLTA, bahkan diasumsikan sampai saat ini kondisi tersebut relatif belum ada perubahan ke arah yang lebih baik.

Tingginya tingkat pengangguran tersebut menunjukkan lemahnya pengembangan sumber daya manusia (SDM) dan sistem pendidikan yang belum mampu menghasilkan lulusan yang bermutu dan produktif bagi pertumbuhan ekonomi. Relevansi pendidikan bagi dunia kerja dan masyarakat perlu mendapat perhatian yang serius. Hal ini disebabkan pengelolaan pendidikan selama ini diibaratkan sebagai lokomotif yang dijalankan secara birokratik dan sentralistik.

Menurut Unit Facilitation Development Project: Bidang Otonomi Pendidikan, Departemen Pendidikan Nasional (2004) memperkirakan potensi disintegrasi dalam bidang pendidikan terbentuk disebabkan oleh: 1) budaya yang ditimbulkan akibat sentralisasi pengelolaan pendidikan; 2) kesenjangan mutu yang sangat tajam antar daerah/wilayah, antara desa-kota, antara kaya-miskin; 3) kondisi sumberdaya pendidikan yang sangat beragam antarsegmen masyarakat; 4) pendidikan karakter bangsa yang masih bersifat indoktrinatif sehingga belum mampu menumbuhkan pluralisme dan demokrasi; 5) alokasi anggaran pendidikan yang belum memihak pada masyarakat "miskin", dan 6) kemampuan aparat dan tenaga profesional daerah masih beragam dalam pengelolaan pendidikan.
Hal tersebut ditunjang oleh fakta yang menunjukan bahwa semenjak diundangkannya Undang-Undang Sistem Pendidikan Nasional (UUSPN) Nomor 20/2003, pelaksanaan otonomi pendidikan belum sepenuhnya sesuai dengan yang diharapkan. Beberapa faktor yang menjadi penyebabnya antara lain: 1) belum meratanya kesiapan SDM untuk mengelola pendidikan di daerah masing-masing; 2) keterbatasan tersedianya pendanaan APBD; 3 ) belum optimalnya keterlibatan masyarakat terhadap pendidikan; 4) bervariasi cara pandang masyarakat terhadap pembangunan bidang pendidikan di masing-masing daerah, dan 5) belum merata ketersediaan sarana-prasarana pendidikan di daerah (http://pokguruonline. pendidikan.net).

Dengan dilaksanakannya otonomi daerah dan desentralisasi fiskal, sektor pendidikan merupakan salah satu sektor bidang pelayanan dasar yang mengalami perubahan secara fundamental, baik dari segi birokrasi kewenangan penyelenggaraan pendidikan maupun dari aspek pendanaannya. Di samping itu, Peraturan Pemerintah (PP) tentang Pemerintah Daerah dan Perimbangan Keuangan Pusat-Daerah sebagai acuan dalam memfasilitasi implikasi otonomi daerah terhadap bidang pendidikan. Atas dasar tersebut, dapat disintesisikan bahwa agar pelaksanaan desentralisasi pendidikan dapat dilaksanakan oleh masing-masing daerah maka pelaksanaannya perlu dilakukan secara bertahap dan berkesinambungan sesuai dengan kesiapan/ kondisi masing-masing daerah.

Berkaitan dengan uraian di atas, permasalahan yang dirumuskan sebagai berikut: 1 ) prinsip-prinsip dan kewenangan desentralisasi pendidikan serta pentahapan desentralisasi seperti apa yang dapat mempengaruhi faktorfaktor yang menentukan efektifitas penyelenggaraan pendidikan? dan 2) apa implikasi otonomi daerah dan desentralisasi fiskal terhadap desentralisasi pendidikan di Indonesia dalam rangka meningkatkan mutu dan relevansi pendidikan?

Tujuan penulisan artikel ini dimaksudkan untuk mengkaji implikasi implementasi UndangUndang Pemerintahan Daerah dan UndangUndang Perimbangan Keuangan Pusat-Daerah terhadap desentralisasi pendidikan dikaitkan dengan UUSPN Nomor 20/2003 dengan mem- 
bahas: 1) prinsip-prinsip dan kewenangan desentralisasi pendidikan serta bagaimana proses desentralisasi dapat mempengaruhi faktor-faktor yang akan menentukan efektifitas penyelenggaraan pendidikan dan 2) implikasi otonomi daerah dan desentralisasi fiskal terhadap tahaptahap desentralisasi pendidikan di Indonesia dalam rangka meningkatkan mutu dan relevansi pendidikan.

\section{Kajian Literatur dan Pembahasan Pengertian Desentralisasi}

Pada hakikatnya "desentralisasi "adalah penyerahan kewewenangan pemerintahan Pemerintah Pusat kepada pemerintah daerah otonom untuk mengatur dan mengurus urusan pemerintahan dalam sistem Negara Kesatuan Republik Indonesia ( UU Nomor 32/ 2004, Pasal 1 angka 7 Desentralisasi). Penyerahan kewewenangan tersebut diwujudkan dalam bentuk: 1) Dekonsentrasi, merupakan pelimpahan wewenang pemerintahan oleh Pemerintah Pusat kepada Gubernur sebagai wakil pemerintah dan/ atau kepada instansi vertikal di wilayah tertentu (UU No.32/2004 Pasal 1 angka 8) dan 2) Tugas pembantuan, merupakan penugasan dari Pemerintah Pusat kepada daerah dan/atau desa dari pemerintah provinsi kepada kabupaten/kota dan/atau desa serta dari pemerintah kabupaten/ kota kepada desa untuk melaksanakan tugas tertentu. (UU No.32/2004 Pasal 1 angka 9).

\section{Prinsip-Prinsip Desentralisasi Pendidikan}

Desentralisasi pendidikan yang dilakukan di berbagai negara merupakan bagian dari proses reformasi pendidikan secara keseluruhan dan tidak sekedar merupakan bagian dari proses otonomi daerah dan desentralisasi keuangan (Burki, et. al., 1999). Lebih lanjut, desentralisasi pendidikan merupakan proses pemberian kewenangan yang lebih luas di bidang kebijakan pendidikan dan aspek pendanaannya dari Pemerintah Pusat ke pemerintah daerah dan pada saat yang bersamaan kewenangan yang lebih besar diberikan pula kepada sekolah dalam bentuk manajemen berbasis sekolah (MBS).

Konsekuensi logis dalam pelaksanaan desentralisasi berdampak pada berbagai sektor, antara lain sektor pendidikan yang notabene menyangkut sistem pendidikan nasional. Oleh karena itu, Pemerintah merasa perlu untuk melakukan penyesuaian terhadap UUSPN Nomor 2/1989 menjadi UUSPN Nomor 20/2003. Perubahan yang cukup mendasar terhadap UU tersebut antara lain: 1) aspek demokratisasi dan desentralisasi pendidikan; 2) peran serta masyarakat, dan 3) tantangan global.

Perubahan pengelolaan pendidikan secara otonom, sekurang-kurangnya diasumsikan akan berdampak terhadap: a) perluasan dan pemerataan akses pendidikan; b) peningkatan mutu dan relevansi pendidikan; c) efesiensi keuangan; dan d) efisiensi administrasi. Oleh karena itu, desentralisasi pendidikan memerlukan landasan demokrasi yang kuat, transparan, dan efisien, serta melibatkan para pemangku kepentingan (stakeholders).

Secara konseptual, terdapat dua jenis desentralisasi pendidikan, yaitu: 1) desentralisasi kewenangan di bidang pendidikan dalam hal kebijakan pendidikan dan aspek pendanaannya dari Pemerintah Pusat ke pemerintah daerah (provinsi, kabupaten/kota) dan 2) desentralisasi pendidikan dengan fokus pada pemberian kewenangan yang lebih besar di tingkat sekolah. Konsep desentralisasi pendidikan yang pertama terutama berkaitan dengan otonomi daerah dan desentralisasi penyelenggaraan pemerintahan dari Pusat ke daerah, sedangkan konsep desentralisasi pendidikan yang memfokuskan pada pemberian kewenangan yang lebih besar pada tingkat sekolah dilakukan dengan motivasi untuk meningkatkan kualitas hasil pendidikan (Burki, et. al. 1999).

Tujuan dan orientasi dari desentralisasi pendidikan sangat bervariasi berdasarkan pengalaman desentralisasi pendidikan yang dilakukan di beberapa negara seperti Amerika Latin, Amerika Serikat, dan Eropa. Manakala desentralisasi yang menjadi tujuan adalah pemberian kewenangan di bidang pendidikan yang lebih besar kepada pemerintah daerah, maka fokus desentralisasi pendidikan yang dilakukan adalah pada pelimpahan kewenangan yang lebih besar kepada pemerintah daerah atau kepada dewan pendidikan dan/atau komite sekolah. Implisit ke dalam strategi desentralisi pendidikan yang seperti ini merupakan target untuk mencapai efisiensi dalam pemberdayaan sumber daya (tenaga, material dan dana pendidikan berasal dari Pemerintah dan masyarakat). 
Selanjutnya, manakala yang menjadi tujuan desentralisasi pendidikan adalah peningkatan kualitas proses belajar-mengajar dan kualitas dari hasil proses belajar-mengajar tersebut maka desentralisasi pendidikan lebih difokuskan pada reformasi proses belajar-mengajar. Dalam hal ini, partisipasi orang tua dalam proses belajarmengajar dianggap merupakan salah satu faktor yang menentukan.

Dari pengalaman negara-negara maju atau Organization for Economic Cooperation and Development (OECD) dan beberapa negara Amerika Latin yang telah melakukan desentralisasi pendidikan, Patrinos, Harry A. and David L. Ariasingam (1997) menyimpulkan bahwa di negara-negara yang tergabung dalam OECD, kewenangan-kewenangan dalam hal penentuan buku pelajaran, metode pembelajaran, tanggung jawab dalam pelaksanaan rencana pengembangan sekolah cenderung berlaku di tingkat sekolah dan tidak tergantung pada tingkat desentralisasi dalam penyelenggaraan pemerintahan.

Adapun tipologi komponen-komponen bidang pendidikan yang dapat dipertimbangkan untuk didesentralisasikan sebagaimana pada Tabel 1 .

Hasil pengamatan desentralisasi pendidikan di negara-negara Amerika Latin, menunjukkan bahwa kewenangan dalam menentukan kurikulum inti tetap berada pada Pemerintah Pusat. Demikian pula dengan kewenangan dalam melaksanakan ujian-ujian yang diberlakukan secara nasional. Hal ini berlaku secara umum di negara-negara Amerika Latin dan tidak tergantung pada tingkat desentralisasi dalam penyelenggaran pemerintahan dari masingmasing negara bagian. Desentralisasi pendidikan yang terjadi di negara-negara Amerika Latin merupakan bagian dari desentralisasi politik dan fiskal penyelenggaraan pemerintahan, dari sistem pendidikan yang sentralistik ke sistem yang memberikan kewenangan lebih besar pada pemerintah daerah yang melibatkan partisipasi masyarakat. Diharapkan, desentralisasi pendidikan akan mampu meningkatkan kuantitas dan kualitas pendidikan. Salah satu cara dalam mempersiapkan desentralisasi pendidikan adalah dengan mengidentifikasi faktor-faktor yang mempengaruhi proses dan hasil belajar-mengajar, khususnya dari sekolah-sekolah unggulan.

Mohrman and Wohlstetter (1994), Creemers (1994) and Darling-Hammond, (1997) sebagaimana dikutip Burki, et.al., (1999) menyimpulkan bahwa sekolah unggulan memiliki karakteristikkarakteristik: a) kepemimpinan yang kuat, b) staf pengajar dengan kualifikasi dan komitmen tinggi,

Tabel 1. Tipologi kewenangan pendidikan yang dapat disentralisasikan

\begin{tabular}{|l|l|}
\hline \multicolumn{1}{|c|}{ Komponen } & \multicolumn{1}{c|}{ Kewenangan } \\
\hline $\begin{array}{l}\text { Organisasi dan proses } \\
\text { belajar-mengajar }\end{array}$ & $\begin{array}{l}\text { 1. Menentukan sekolah mana yang dapat diikuti peserta } \\
\text { 2. Wdik }\end{array}$ \\
& $\begin{array}{l}\text { 2. Waktu belajar di sekolah } \\
\text { 3. Penentuan buku teks }\end{array}$ \\
& 4. Kurikulum \\
\hline Manajemen guru & 1. Metode pembelajaran \\
\hline Struktur dan perencanan & 2. Memilih dan memberhentikan kepala sekolah \\
& 3. Menentukan gaji guru \\
& 4. Memberikan tanggung jawab pengajaran kepada guru \\
& 5. Menentukan dan memebrikan pelatihan kepada guru \\
\hline Sumber daya & 2. Menentukan program yang ditawarkan sekolah \\
& 4. Pengawinasan atas kinerja sekolah \\
\hline & 1. Program pengembangan sekolah \\
& 2. Alokasi anggaran guru dan tenaga administrasi \\
& 3. Alokasi anggaran nonpersonel \\
& 4. Alokasi anggaran untuk pelatihan guru \\
\hline
\end{tabular}

Sumber: Organization for Economic Cooperation and Development (OECD) dalam Burki, et. al. (1999: 57). 
c) fokus pada proses pembelajaran, dan d) bertanggung jawab terhadap hasil yang dicapai (akuntabilitas publik).

Proses desentralisasi bidang pendidikan yang meliputi pemberian kewenangan yang lebih besar ke pemerintah daerah dalam alokasi anggaran dan perencanaan pendidikan di daerah, serta pemberian kewenangan yang lebih besar pada sekolah dalam hal manajemen guru, pendanaan, pemilihan kepala sekolah, manajemen proses belajar-mengajar dimaksudkan untuk meningkatkan kualitas dan relevansi pendidikan.

Oleh karena itu, penyelenggaraan desentralisasi pendidikan diharapkan akan muncul sekolah-sekolah yang efktif mengacu pada prinsip manajemen berbasis sekolah (MBS). Pada hakikatnya, MBS merupakan bentuk kewenangan Pemerintah Pusat ke satuan pendidikan (sekolah) dalam mengelola program kegiatan pembelajaran di sekolah masing-masing melalui musyawarah seluruh komponen warga sekolah (kepala sekolah, guru, siswa, orangtua siswa, masyarakat, komite sekolah dan/atau para peemangku kepentingan (stakeholders) lainnya. Dengan kata lain, seluruh aktvitas sekolah dilaksanakan atas dasar musyawarahdan dan mufakat antara warga sekolah.

Lebih lanjut, figur kepala sekolah diharapkan seseorang yang memiliki manajerial skill yang handal dan dipilih secara transparan melalui tahapan proses pemilihan dari pencalonan sampai penetapan calon jadi dengan mengikuti berbagai penilaian (tes) khusus (talent schouting) dengan tetap mempertimbangkan suara warga sekolah sebelum ditetapkan sebagai kepala sekolah. Jabatan kepala sekolah ditetapkan berdasarkan kurun waktu tertentu dan dapat diperpanjang sepanjang yang bersangkutan memiliki prestasi yang terukur dan dapat dipertanggungjawabkan secara transparan. Dalam menetapkan agenda kegiatan dan pendanaannya selalu berorientasi pada kesepakatan atas dasar musyawarah dan mufakat dengan seluruh komponen warga sekolah.

Profil guru, diharapkan selain mengikuti ketetapan peraturan perundang-undangan terkait dengan kualifikasi pendidikan minimum, sertifikasi, dan kompetensi, guru memiliki otonomi untuk merencanakan rancangan program pengajaran (RPP) sesuai dengan sarana dan prasarana yang ada dan mengembangkan kurikulum sesuai dengan tingkat kebutuhan peserta didik. Guru secara periodik mengikuti penilaian diri (self evaluation) dan/atau penilaian antar teman sejawat dan penilaian dari atasan (kepala sekolah). Di samping itu, agar guru selalu mengikuti perkembangan ilmu pengetahuan dan teknologi diberi hak untuk mengikuti berbagai

\section{Tabel 2. Karakteristik sekolah yang efektif}

\begin{tabular}{|c|c|}
\hline $\begin{array}{l}\text { Karakteristik sekolah } \\
\text { yang efektif }\end{array}$ & Variabel desentralisasi yang akan memperkuat sekolah efektif \\
\hline Kepemimpinan & $\begin{array}{l}\text { 1. Kepala sekolah dipilih oleh masyarakat dengan kriteria yang } \\
\text { transparan } \\
\text { 2. Program pengembangan sekolah disusun pada tingkat lokal } \\
\text { 3. Penggalian dana untuk melaksanakan program-program } \\
\text { sekolah }\end{array}$ \\
\hline $\begin{array}{l}\text { Guru dengan kualifikasi } \\
\text { dan komitmen yang tinggi }\end{array}$ & $\begin{array}{l}\text { 1. Sekolah diberi kewenangan untuk mengubah kurikulum dan } \\
\text { proses pembelajaran } \\
\text { 2. Kepala sekolah diberi kewenangan untuk mengevaluasi } \\
\text { guru } \\
\text { 3. Sekolah diberi kewenangan menentukan prasarana/dana } \\
\text { untuk menentukan sendiri program pelatihan bagi guru }\end{array}$ \\
\hline $\begin{array}{l}\text { Fokus pada proses } \\
\text { pembelajaran }\end{array}$ & $\begin{array}{l}\text { 1. Program pengembangan dan peningkatan kualitas sekolah } \\
\text { menekankan pada aspek peningkatan proses pembelajaran } \\
\text { 2. Keterbukaan pengembangan dan peningkatan kualitas } \\
\text { sekolah menekankan pada aspek pembelajaran yang } \\
\text { dilaksanakan sekolah }\end{array}$ \\
\hline $\begin{array}{l}\text { Bertanggungjawab atas } \\
\text { keberhasilan yang dicapai }\end{array}$ & $\begin{array}{l}\text { 1. Kepala sekolah diangkat berdasarkan masa jabatan, } \\
\text { perpanjangan masa jabatan tergantung pada prestasi } \\
\text { dalam memenuhi target peningkatan proses pembelajaran } \\
\text { di sekolah }\end{array}$ \\
\hline
\end{tabular}

Sumber: Burki, et.al (1999: 61) 
pelatihan profesional yang sifatnya memperbaharui/menguatkan maupun meningkatkan kompetensi. Dengan kata lain, guru sebagai tenaga profesional selalu komitmen dalam menjalankan tugas dan kebutuhannya untuk mengikuti perkembangan ilmu pengetahuan dan teknologi sesuai dengan kebutuhan masingmasing. Seluruh aktivitas sekolah, di samping berdasarkan pada program-program akademik yang telah ditetapkan bersama oleh para pemangku kepentingan juga diagendakan berbagai kegiatan nonakademik (ekstra-kurikuler) didasarkan pada minat dan bakat yang terbimbing. Dengan demikian, program kegiatan di sekoah tidak hanya menekankan pada proses, namun juga produk yang berkualitas. Tabel berikut menujukkan beberapa indikator karakteristik sekolah eefektif (Burki, et.al (1999: 61).

\section{Sistem Sentralisasi ke Sistem Desentralisasi Pendidikan}

Sistem pendidikan yang berlaku sebelum otonomi daerah bersifat sentralistis, yang dimulai dari pemberlakuan satu kurikulum secara nasional sampai dengan peranan pusat yang sangat dominan dalam pengelolaan guru (khusus bagi sekolah negeri). Pusat sangat dominan dan menentukan dalam setiap keputusan tentang proses rekrutmen, pengangkatan, penempatan, pembinaan dan mutasi guru, begitu pula dari aspek keuangan. Gaji guru sekolah negeri ditetapkan dan dibayarkan Pemerintah meskipun gaji bagi guru SD pengelolaannya dilaksanakan oleh provinsi, sedangkan gaji guru SLTP dan SLTA langsung oleh Pemerintah Pusat melalui KPKN.

Dari segi dana di luar gaji yang dialokasikan Pemerintah ke masing-masing sekolah, diberikan dengan cara alokasi dana dari pusat ke daerah (kabupaten/kota) berdasarkan jumlah sekolah yang ada di daerah tersebut. Mekanisme alokasi dana dilakukan dengan perhitungan sejumlah dana yang sama untuk setiap sekolah berdasarkan jenjang pendidikan, tanpa memperhitungkan jumlah murid, lokasi ataupun tingkat kemakmuran ekonomi daerah tersebut. Cara seperti ini mengandung banyak kelemahan, karena tidak memperhatikan sisi pemerataan (equity) dan kebutuhan dalam pengalokasian dana ke masingmasing sekolah (umum dan kejuruan).

Melalui proses desentralisasi yang diimplementasikan Pemerintah melalui UU UU Nomor 32/
2004 tentang Pemerintahan Daerah dan UU Nomor 33/2004 tentang Perimbangan Keuangan Pusat-Daerah dapat diasumsikan bahwa prinsipprinsip dan arah baru dalam pengelolaan bidang pendidikan mengacu pada pembagian kewenangan antara Pemerintah Pusat, provinsi, dan kabupaten/kota, serta perimbangan keuangan Pusat-daerah dengan garis besarnya sebagai berikut.

\section{Kewenangan Pemerintah Pusat}

Pemerintah Pusat masih memiliki beberapa kewenangan, yaitu: melaksanakan kewenangankewenangan Pemerintah dalam bidang-bidang: 1) Pertahanan/Keamanan, 2) Politik Luar Negeri, 3) Peradilan, 4) Fiskal/Moneter, dan 5) Agama serta 6) Kewenangan bidang pemerintahan lainnya dan/ atau kebijakan strategis yang ditetapkan dengan Peraturan Pemerintah. Bidang lainnya yang tetap menjadi kewenangan Pemerintah Pusat adalah: (i) Perencanaan nasional dan pengendalian pembangunan sektoral dan nasional secara makro; (ii) Kebijakan dana perimbangan keuangan; (iii) Kebijakan sistem administrasi negara dan lembaga perekonomian negara; (iv) Kebijakan pembinaan dan pemberdayaan sumberdaya manusia; (v) Kebijakan pendayagunaan teknologi tinggi dan strategis, serta pemanfaatan kedirgantaraan, kelautan, pertambangan dan kehutanan/lingkungan hidup; (vi) Kebijakan konservasi; (vii) Kebijakan standarisasi nasional.

\section{Kewenangan Pemerintah Provinsi}

Kewenangan bidang pemerintahan yang bersifat lintas kabupaten dan kota yang menjadi tanggung jawab provinsi, misalnya adalah kewenangan di bidang pekerjaan umum, perhubungan, kehutanan, dan perkebunan disamping kewenangan bidang pemerintahan tertentu lainnya. Kewenangan bidang pemerintahan tertentu lainnya mencakup: (i) Perencanaan pembangunan regional secara makro; (ii) Pelatihan kejuruan dan alokasi sumber daya manusia potensial; (iii) Pelabuhan regional; (iv) Lingkungan hidup; (v) Promosi dagang dan budaya/pariwisata; (vi) Penanganan penyakit menular dan hama tanaman; (vii) Perencanaan tata ruang provinsi. 


\section{Kewenangan Pemerintah Kabupaten/Kota}

Mencakup semua kewenangan Pemerintahan selain kewenangan Pemerintah Pusat dan provinsi. Secara eksplisit dinyatakan bahwa bidang pemerintahan yang wajib dilaksanakan daerah kabupaten dan daerah kota meliputi: pekerjaan umum, kesehatan, pendidikan, pertanian, perhubungan, perdagangan dan industri, enanaman modal, lingkungan hidup, dan pertanahan. Kewenangan bidang pemerintahan tertentu lainnya mencakup: (i) Perencanaan pembangunan regional secara makro; (ii) Pelatihan kejuruan dan alokasi sumber daya manusia potensial; (iii) Pelabuhan regional; (iv) Lingkungan hidup; (v) Promosi dagang dan budaya/pariwisata; (vi) Penanganan penyakit menular dan hama tanaman; (vii) Perencanaan tata ruang Provinsi.

\section{Perimbangan Keuangan Pusat-Daerah}

Dari aspek fiskal/keuangan negara, Perimbangan Keuangan Pusat-Daerah menurut UU Nomor 33/ 2004 (UU-PKPD) mengatur pembagian keuangan antara Pemerintah Pusat dan Daerah, dengan mempertimbangkan aspek pemerataan antar daerah, potensi, kondisi, kebutuhan obyektif daerah serta tata cara pengelolaan dan pengawasan pelaksanaannya. Sumber-sumber penerimaan daerah menurut UU-PKPD meliputi:

(i) Pendapatan Asli Daerah (PAD); (ii) Dana Perimbangan; (iii) Pinjaman Daerah; (iv) Lain-lain pendapatan yang sah. Daerah melaksanakan semua kewenangannya yang berkaitan dengan desentralisasi dengan dibiayai dari anggaran daerah.

Penerimaan daerah yang berupa PAD masih mengacu pada UU Nomor 18/1997 tentang Pajak Daerah dan Retribusi Daerah. Dana Perimbangan terdiri atas bagian daerah atas hasil Sumber Daya Alam, Pajak Bumi dan Bangunan, Bea Perolehan Hak atas Tanah dan Bangunan; Dana Alokasi Umum dan Dana Alokasi Khusus. Dana Alokasi Umum merupakan transfer dari pusat ke daerah dalam bentuk block grant, dengan kriteria alokasi berdasarkan potensi ekonomi daerah dan kebutuhan obyektif daerah. Penggunaan Dana Alokasi Umum diserahkan sepenuhnya pada daerah Dana Alokasi Khusus merupakan transfer dari pusat ke daerah yang bersifat spesifik, yang peruntukannya ditetapkan pusat. Dana Alokasi Umum (DAU) didistribusikan: a) berfungsi sebagai dana untuk pemerataan antar daerah; b) besarnya DAU ditetapkan minimal 25\% dari penerimaan dalam negeri APBN dengan pembagian $10 \%$ untuk Provinsi dan $90 \%$ untuk kabupaten/kota; dan c) DAU untuk suatu daerah provinsi (kabupaten/kota) tertentu ditetapkan berdasarkan perkalian jumlah DAU untuk seluruh daerah provinsi (kabupaten/kota) yang ditetapkan dalam APBN dengan porsi daerah provinsi (kabupaten/kota) yang bersangkutan. Porsi daerah provinsi (kabupaten/kota) merupakan proporsi bobot daerah provinsi (kabupaten/kota) yang bersangkutan terhadap jumlah semua daerah provinsi (kabupaten/kota) yang bersangkutan. Bobot daerah ditetapkan berdasarkan kebutuhan wilayah otonomi daerah dan potensi ekonomi daerah.

Berkaitan dengan pendanaan, UU No. 33/ 2004 Pasal 1 angka 13 mengamanatkan bahwa perimbangan keuangan antara Pemerintah dan pemerintahan daerah adalah suatu sistem pembagian keuangan yang adil, proporsional, demokratis, transparan, dan bertanggung jawab dalam rangka pendanaan penyelenggaraan desentralisasi, dengan mempertimbangkan potensi, kondisi, dan kebutuhan daerah serta besaran pendanaan penyelenggaraan dekonsentrasi dan tugas pembantuan. Dengan demikian, dengan adanya dukungan pendanaan tersebut daerah diharapkan dapat melaksanakan limpahan kewenangan dari Pemerintah sesuai dengan kebutuhan, kondisi, dan situasi masyarakat setempat, dengan tetap mengatur dan mengurus urusan pemerintahan dalam bingkai sistem Negara Kesatuan Republik Indonesia (NKRI).

\section{Implikasi Terhadap Desentralisasi Pendidikan}

Implikasi otonomi daerah terhadap desentralisasi pendidikan sangat tergantung pada pembagian kewenangan di bidang pendidikan yang akan ditangani Pemerintah Pusat, pemerintah provinsi dan pemerintah kabupaten/kota. Mengacu pada UU Nomor 32 /2004, maka kewenangan di sektor pendidikan yang terkait dengan: (i) perencanaan nasional dan pengendalian pembangunan sektoral dan nasional secara makro; (ii) kebijakan pembinaan dan pemberdayaan SDM; (iii) kebijakan standarisasi nasional akan ditangani pusat, lainnya akan ditangani daerah, khususnya daerah kabupaten/kota.

Ace Suryadi (2004) memerinci urusan otonomi 
pendidikan sebagai berikut: 1) Kewenangan Pendidikan pada Pemerintah Pusat, meliputi: kebijakan nasional, standar/norma pendidikan, pendidikan karakter bangsa, pengendalian dan jaminan mutu pendidikan (educational quality control), dan pendidikan tinggi; 2) ; 2$)$ Kewenangan pendidikan pada pemerintah provinsi, meliputi: Pendidikan luar biasa, LPTK, pendidikan lintas kabupaten, koordinasi, guru dan tenaga pendidik lainnya; dan 3) Kewenangan Pendidikan pada Pemerintah Kabupaten/Kota, meliputi: Pendidikan dasar, pendidikan menengah koordinasi dengan Provinsi, PAUD, PNF kepemudaan, keolahragaan, statistik pendidikan, dan pendidikan masyarakat.

Nampaknya masih belum jelas benar interpretasi pelaksanaan desentralisasi di bidang pendidikan dengan mengacu UU Nomor 32/2004 karena belum ada standar mutu yang jelas. Terkait dengan status guru, apakah status guru sebagai PNS pusat atau daerah akan sangat berpengaruh pada alokasi anggaran, pembiayaan melalui APBN atau APBD. Implikasi lain dari status guru adalah fleksibilitas daerah dan sekolah dalam proses rekrutmen, pengangkatan, penempatan, mutasi, pemberhentian guru, serta evaluasi atas kinerja guru. Namun demikian, sekarang kecendrungannya kembali menjadi kewenangan daerah sekalipun pada hakikatnya pembayaran gaji guru bersumber dari APBN yang didaerahkan (APBD). Pengembangan kurikulum, kisi-kisi kurkulum berbasis kompetensi menjadi tanggungjawab Pemerintah Pusat, sedangkan secara operasional materi dapat dikembangkan oleh satuan pendidikan dalam bentuk Kurikulum Tingkat Satuan Pendidikan (KTSP) yang dikembangkan sesuai dengan kondisi sekolah dan kebutuhan peserta didik. Dalam pengembangan kurikulum, kisi-kisi kurkulum berbasis kompetensi menjadi tanggungjawab Pemerintah Pusat, sedangkan secara operasional materi dapat dikembangkan oleh satuan pendidikan yang dikembangkan sesuai dengan kondisi sekolah dan kebutuhan peserta didik.

Mengenai alokasi dana dari pusat ke daerah, sampai telah ada kejelasan tentang perumusan alokasi DAU dan DAK ke daerah. Dana Alokasi Khusus (DAK): a) Dialokasikan dari APBN kepada daerah tertentu untuk membantu pembiayaan kebutuhan khusus dengan memperhatikan tersedianya dana dalam APBN; b) Kebutuhan khusus adalah kebutuhan yang tidak dapat diperkirakan dengan menggunakan rumus DAU, dan/atau kebutuhan yang merupakan komitmen atau prioritas nasional apakah dana yang ditransfer pusat sebagai DAU sudah mencakup alokasi anggaran rutin dan pembangunan untuk sektor pendidikan? Ataupun dana yang termasuk dalam transfer DAU hanya diperuntukan bagi pembiayaan pengeluaran-pengeluaran nonpersonnel dari sektor pendidikan. Hal-hal seperti ini akan sangat tergantung pada keputusan untuk tetap mempertahankan status guru sebagai PNS Pusat atau mendesentralisasikan pengelolaan guru kepada daerah sepenuhnya. Demikian pula dengan alokasi DAK ke daerah, sektor prioritas apa saja yang masih diberikan DAK ke daerah, kriteria pengalokasiannya dan apakah sektor pendidikan termasuk sektor yang akan diberikan DAK, misalnya untuk daerah-daerah dengan pencapaian standar tingkat pendidikan dibawah rata-rata nasional. Jika dana pendidikan untuk rutin (gaji guru) dan non-rutin ditransfer sepenuhnya ke daerah melalui mekanisme DAU, maka berapa besar yang akan dialokasikan ke sektor pendidikan akan tergantung pada prioritas masing-masing daerah.

Prioritas alokasi dana daerah selanjutnya tergantung pada pemerintah daerah dan DPRD setempat. Mengingat sektor pendidikan merupakan salah satu sektor pelayanan dasar, masih perlu adanya suatu ketentuan standar minimal pendidikan yang harus dicapai daerah, sehingga daerah memiliki acuan yang harus dicapai dalam perencanaan sektor pendidikan. Pertanyaan terpenting tentang arah desentralisasi pendidikan adalah sampai seberapa jauh sekolah-sekolah akan diberi kewenangan yang lebih besar menentukan kebijakan kebijakan tentang organisasi dan proses belajar-mengajar, manajemen guru, struktur dan perencanaan di tingkat sekolah, dan sumber-sumber pendanaan sekolah.

\section{Prinsip-Prinsip Penyelenggaraan Pendidikan}

Berdasarkan UUSPN Nomor 20/2003, prinsip penyelenggaraan pendidikan sebagaimana dimaksud pada Bab III dalam Pasal 4 ayat (1), ayat (3), dan ayat (6), UUSPN, antara lain menyebutkan bahwa: a) pendidikan diselenggarakan secara demokratis dan berkeaadilan serta tidak diskriminatif dengan menjunjung tinggi hakhak asasi manusia, nilai keagamaan, nilai kultural, 
dan kemajemukan bangsa (ayat 1); b) Pendidikan diselenggarakan sebagai satu kesatuan yang sistemik dengan sistem terbuka dan multimakna (ayat 2), c) pendidikan diselenggarakan sebagai proses pembudayaan dan pemberdayaan peserta didik yang berlangsung sepanjang hayat (ayat 3 ), dan d) pendidikan diselenggarakan dengan memberdayakan semua komponen masyarakat melalui peran serta dalam penyelenggaraan dan pengendalian layanan mutu pendidikan (ayat 6). Ayat-ayat tersebut mengamanatkan bahwa pada hakikatnya pendidikan merupakan hak setiap warga negara, berlangsung sepanjang hayat, diselenggarakan tanpa diskriminasi,terbuka dan multi makna, serta seluruh komponen masyarakat (stakeholders) ikut bertanggung jawab.

Penyelenggaraan pendidikan tanpa diskriminasi berarti pendidikan membuka peluang bagi siapa saja, yang berarti pula memberi peluang yang sama bagi setiap warga negara mengenyam pendidikan. Hal ini peserta didik memiliki otonomi memilih pendidikan yang dikehendaki sesuai dengan kondisi, potensi dan kemampuan yang dimiliki. Disisi lain, pendidikan dengan sistem terbuka merupakan pendidikan yang diselenggarakan dengan fleksibilitas pilihan dan waktu penyelesaian program lintas satuan dan jalur pendidikan (multi entry-multi exit system) dimana peserta didik dapat belajar sambil bekerja, atau mengambil program-program pendidikan pada jenis dan jalur pendidikan yang berbeda secara terpadu dan berkelanjutan melalui pembelajaran tatap muka atau jarak jauh. Pemerintah Indonesia dalam mewujudkan "mencerdaskan kehidupan bangsa" telah memberikan kesempatan pendidikan bagi semua warga negaranya untuk mengikuti atau memberi kesempatan bagi warga negaranya untuk mengikuti pendidikan, baik melaui jalur pendidikan formal, nonformal maupun informal sesuai dengan kesempatan masing-masing (Siswo Wiratno, 2009).

Berbagai peraturan perundang-undangan telah disiapkan sebagai payung hukum dalam penyelenggaraan dan pengelolaan pendidikan sebagai turunan UU Sistem Pendidikan Nasional, yaitu: 1) Undang- Undang Republik Indonesia Nomor 20 /2003 Tentang Sistem Pendidikan Nasional, 2) Peraturan Pemerintah Republik Indonesia Nomor 19 Tahun 2005 tentang Standar Nasional Pendidikan sebagai acuan dalam menciptakan pendidikan yang terstandar dan bermutu, 3) Peraturan Pemerintah Republik Indonesia Nomor 55/2007 tentang Pendidikan agama dan Pendidikan Keagamaan yang didalamnya mengatur pendidikan agama dan pendidikan keagamaan yang diakui di Indonesia, yakni agama Islam, Kristen, Katolik, Hindu, Buddha, serta agama Khonghucu, sebagai wujud amanat Pasal 30 ayat (2) dan Pasal 31 ayat (3) UUD 1945, 4) Peraturan Pemerintah Republik Indonesia Nomor 47 Tahun 2008 tentang Wajib Belar yang mengatur pelaksanaan program wajib belajar sebagai wujud amanat Pasal 31 ayat (2) UUD 1945, 5) Peraturan Pemerintah Republik Indonesia Nomor 48 Tahun 2008 tentang Pendanaan Pendidikan sebagai wujud amanat Pasal 31 ayat (4) UUD 1945, 6) Undang- Undang Republik Indonesia Nomor 14 Tahun 2005 Tentang Guru dan Dosen yang mengatur peningkatan mutu dan kesejahteraan guru dan dosen, 7) Peraturan Pemerintah Republik Indonesia Nomor 74 Tahun 2008 tentang Guru yang mengatur lebih rinci tentang peningkatan mutu dan kesejahteraan guru; 8) Peraturan Pemerintah Republik Indonesia Nomor 37 Tahun 2008 tentang Dosen yang mengatur lebih rinci tentang peningkatan mutu dan kesejahteraan dosen; 9) Peraturan Pemerintah Republik Indonesia Nomor 41 Tahun 2009 tentang tunjangan guru besar yang mengatur lebih rinci tentang peningkatan mutu dan kesejahteraan guru besar; 10) Peraturan Pemerintah Republik Indonesia Nomor 17 Tahun 2010 tentang Pengelolaan dan Penyelengaraan Pendidikan yang mengatur lebih rinci tentang pengelolaan dan penyelenggaraan pendidikan.

Dalam hal kewenangan, kecuali pendidikan di bawah tanggungjawab Kementerian Agama (pendidikan keagaaman dan juga pendidikan umum seperti RA, MI, MTs, MA, dan bentuk lain yang sejenis), PAUD jalur formal, pendidikan dasar dan pendidikan menengah menjadi tanggung jawab pemerintah kabupaten/kota, pendidikan luar biasa (PLB) menjadi tanggung jawab pemerintah provinsi, sedangkan pendidikan tinggi menjadi tangujg jawab Pemerintah Pusat. Wujud tanggung jawab masing-masing pemerintah provinsi, kabupaten/kota mengindikasikan adanya otonomi penyelenggaraaan pendidikan sesuai dengan kewenangana masing-masing.

Dalam hal upaya meningkatkan mutu dan relevansi pendidikan di daerah perlu dibentuk 
lembaga penjaminan mutu daerah sebagai kepanjangan otorisasi penjaminan mutu nasional (pusat) yang dalam hal ini disebut dengan badan standarisasi nasional pendidikan provinsi (Anwar Arifin dalam anonim, 2003). Untuk mengantisipasi dan menghadapi tantangan global yang kompetitif diperlukan penyelenggaraan satuan pendidikan bertaraf internasional. Hal ini diharapkan agar pada lulusan mampu bersaing secara kompetitif, baik di tingkat lokal, nasional, maupun global. Di samping itu, sekaligus untuk mengurangi penumpukan peredaran finansial pendidikan di luar negeri karena semakin meningkatnya animo siswa lulusan sekolah Indonesia yang belajar di luar negeri.

Secara teoretis, antara desentralisaasi dan demokratisasi tidak dapat terpisahkan satu sama lain. Secara empirik, desentralisasi dan otonomi daerah tidak hanya terkait dengan persoalan pembagian kewenangan dan keuangan Pemerintah Pusat dan pemerintah daerah, akan tetapi memiliki misi untuk mendekatkan negara dengan masyarakatnya dan dekat dengan pemerintah daerah manakala terjadi desentralisasi dan pemebrian otonomi daerah.

Mengacu pada pendapat Robert Putnam (dalam Sutoro Eko, 2003) berpendapat bahwa desentralisasi dapat menumbuhkan partisipasi dan tradisi kewargaan di tingkat lokal, di mana partisipasi demokrasi telah mengembangkan komitmen WNI secara luas, misalnya dalam bentuk kepercayaan (trust), toleranasi, kerjasama, dan solidaritas atau kita kenal dengan dengan komunitas sipil (civic community). Dalam implementasi otonomi daerah di era reformasi yang mengacu pada UU Nomor 32/2004, memiliki sejumlah kemajuan dibandingkan dengan masamasa sebelumnya.

Sejalan dengan proses desentralisasi yang telah diimplementasikan Pemerintah sejak tahun 2001 melalui UU Nomor 32/2004 dan UU Nomor 33/2004 tentang Pemerintahan Daerah dan Perimbangan Keuangan Pusat-daerah, dapat disimpulkan bahwa prinsip-prinsip dan arah baru dalam pengelolaan bidang pendidikan dengan mengacu pada pembagian kewenangan antara Pemerintah Pusat, provinsi dan kabupaten/kota serta perimbangan keuangan pusat daerah. Bidang pendidikan merupakan salah satu bidang yang termasuk bidang pelayanan dasar yang mengalami perubahan secara mendasar dengan dilaksanakannya otonomi daerah dan desentralisasi fiskal, baik dari segi birokrasi kewenangan penyelenggaraan pendidikan maupun dari aspek pendanaannya.

\section{Pengaturan Kebijakan Pendidikan antara Pusat dan Daerah}

Mengacu pada peraturan perundang-undangan yang menjadi landasan pelaksanaan desentralisasi pendidikan, pada hakikatnya desentralisasi pendidikan telah dilaksanakan, di mana Pemerintah dalam hal ini Kementerian Pendidikan Nasional pusat maupun Kementerian Agama yang membina pendidikan keagaaman telah menetapkan standar dan pedoman pelaksanaan dan juga membina pendidikan tinggi. Pemerintah provinsi melaksanakan koordinasi atas penyelenggaraan pendidikan serta pengembangan tenaga kependidikan, dan penyediaan fasilitas penyelenggaraan pendidikan lintas daerah kabupaten/kota untuk tingkat pendidikan dasar dan menengah dan juga penyelenggaraan satuan pendidikan bertaraf internasional. Pemerintah kabupaten/ kota melaksanakan pendidikan dasar dan menengah dan juga pengembangan pendidikan bertaraf internasional di samping pengembangan pendidikan berbasis keunggulan lokal.

Dengan berlakunya otonomi daerah, maka Pemerintah Pusat tidak lagi diperkenankan mencampuri urusan pembangunan pendidikan daerah. Pemerintah Pusat hanya diperkenankan memberian rambu-rambu pelaksanaan dalam wujud kebijakan nasional dan standar nasional pendidikan. Kebijakan-kebijakan pendidikan yang bersifat nasional, misalnya 3 (tiga) pilar kebijakan Kemdiknas terkait dengan perluasan akses pendidikan, mutu dan relevanasi, serta pencitraan publik, Selain itu, Pemerintah Pusat juga menetapkan Standar Nasional Pendidikan (SNP) sebagaimana diatur dalam PP Nomor 19/2005 yang didalamnya mengatur standar isi, proses, kompetensi lulusan, tenaga kependidikan, sarana dan prasarana pendidikan, pengelolaan, pembiayaan, dan penilaian pendidikan. Oleh karena itu, Pemerintah Pusat hanya berperan sebagai motivator, fasilitator, dan katalisator dalam pembangunan pendidikan. Oleh karena otonomi pengelolaan pendidikan berada pada tingkat sekolah, maka Pemerintah diharapkan mampu dan mau memberi pelayanan prima dan 
utama dalam mendukung proses pendidikan secara efektif dan efisien.

Dalam rangka otonomi daerah, seperti diamanatkan dalam UUSPN Pasal 50 ayat (3), ayat (4), dan ayat (5) Pemerintah, pemerintah provinsi maupun pemerintah kabupaten/kota mengelola pendidikan dasar dan menengah dengan pengaturan kewenangan sebagai berikut: 1) Pemerintah dan/atau pemerintah daerah menyelen-garakan sekurang-kurangnya satu satuan pendidikan pada semua jenjang pendidikan untuk dikembangkan menjadi satuan pendidikan yang bertaraf internasional; 2) Pemerintah daerah provinsi melakukan koordinasi atas penyelenggaraan pendidikan, pengembangan tenaga kependidikan, dan penyediaan fasilitas penyelenggaraan pendidikan lintas daerah kabupaten/kota untuk tingkat pendidikan dasar dan menengah; dan 3) Pemerintah kabupaten/ kota mengelola pendidikan dasar dan pendidikan menengah, serta satuan pendidikan yang berbasis keunggulan lokal. Selanjutnya, untuk pendidikan tinggi, Pasal 50 ayat (6) mengamanatkan bahwa perguruan tinggi menentukan kebijakan dan memiliki otonomi dalam mengelola pendidikan di lembaganya.

\section{Pentahapan Desentraliasi Pendidikan Pada Satuan Pendidikan}

Desentralisasi pendidikan yang efektif tidak hanya melibatkan proses pemberian kewenangan dan pendanaan yang lebih besar dari pusat ke daerah, tetapi juga meliputi pemberian kewenangan yang lebih besar ke sekolah-sekolah setelah ditetapkan standar pelayanan minimal oleh pemerintah pusat, sehingga mereka dapat merencanakan proses belajar-mengajar dan pengembangan sekolah sesuai dengan kondisi dan kebutuhan masing-masing sekolah.

Standar Pelayanan Minimal (SPM) di bidang pendidikan adalah tolok ukur kinerja pelayanan pendidikan yang diselenggarakan daerah. Dalam bentuk pelayanan dasar kepada masyarakat sebagai fungsi Pemerintah dalam memenuhi dan mengurus kebutuhan dasar masyarakat untuk meningkatkan taraf kesejahteraan rakyat. SPM diatur pada tingkatan dan satuan pendidikan yaitu pendidikan dasar, menengah, kejuruan dan pendidikan tinggi (SK Mendiknas No. 129a dan No. 135/U/2004) Tentang Standar Pelayanan Minimal (SPM) Bidang Pendidikan.
Mutu dan relevansi pendidikan dasar, menengah dan tinggi masih sangat rendah sehingga belum mampu mengaktualisasikan potensi sumberdaya manusia Indonesia secara optimal. Beban kurikulum selama ini sangat berat dan cenderung tidak memberi layanan bagi peserta didik yang berdiversifikasi tingkat kemampuan. Keragaman budaya dan latar belakang masyarakat di Indonesia belum menjadi bagian yang memberdayakan dan menginspirasi proses pendidikan. Sebaliknya, yang muncul pada masyarakat justru kemerosotan nilai-nilai perjuangan, wawasan kebangsaan, moral, dan kesantunan, serta meningkatnya keresahan, ketegangan dan kekerasan pada masyarakat. Kesenjangan akses untuk memperoleh pendidikan bermutu terjadi baik secara regional maupun secara stratifikasi ekonomi. Oleh karena itu, untuk sampai pada kemampuan mengelola penyelenggaraan pendidikan pada setiap satuannya diperlukan program yang sistematis dengan melakukan penguatan kapasitas (Capacity Building) tahapan-tahapan yang berkesinambungan dan terukur. Pentahapan ini diimplementasikan pada satuan pendidikan dalam rangka peningkatan mutu pendidikan melalui usaha untuk mencapai SPM dengan memberikan subsidi dan empowerment (seperti Gambar. 1) berikut.

Masing-masing tahapan memiliki ciri-ciri kesetaraan untuk meningkatkan satu kelompok satuan pendidikan. Pada tahap pra-formal, satuan-satuan pendidikan yang belum memiliki standar teknis yang meliputi sumber-sumber pendidikan seperti, guru, prasarana dan sarana pendidikan dan lain sebagainya secara memadai untuk mencapai pelayanan pendidikan secara minimal. Oleh karena itu, pada tahap ini perlu dipenuhi fasilitas minimal pendidikannya terlebih dahulu agar dapat dinaikkan pada tahapan berikutnya, yaitu tahap formalitas. Pada tahap formal, satuan pendidikan yang telah memiliki sumber-sumber pendidikan yang memadai secara minimal, berarti sudah memenuhi standar teknis, maka dalam membangun kapasitasnya dilakukan melalui peningkatan kemampuan administratur (kepala sekolah dan guru-guru, karyawan, instruktur dan tutor) agar dapat melakukan manajemen pendidikan secara efisien, menyelenggarakan proses belajar-mengajar secara kreatif, inovatif dan responsif. Tahapan ini sangat krusial dan dituntut berhasil dalam rangka 


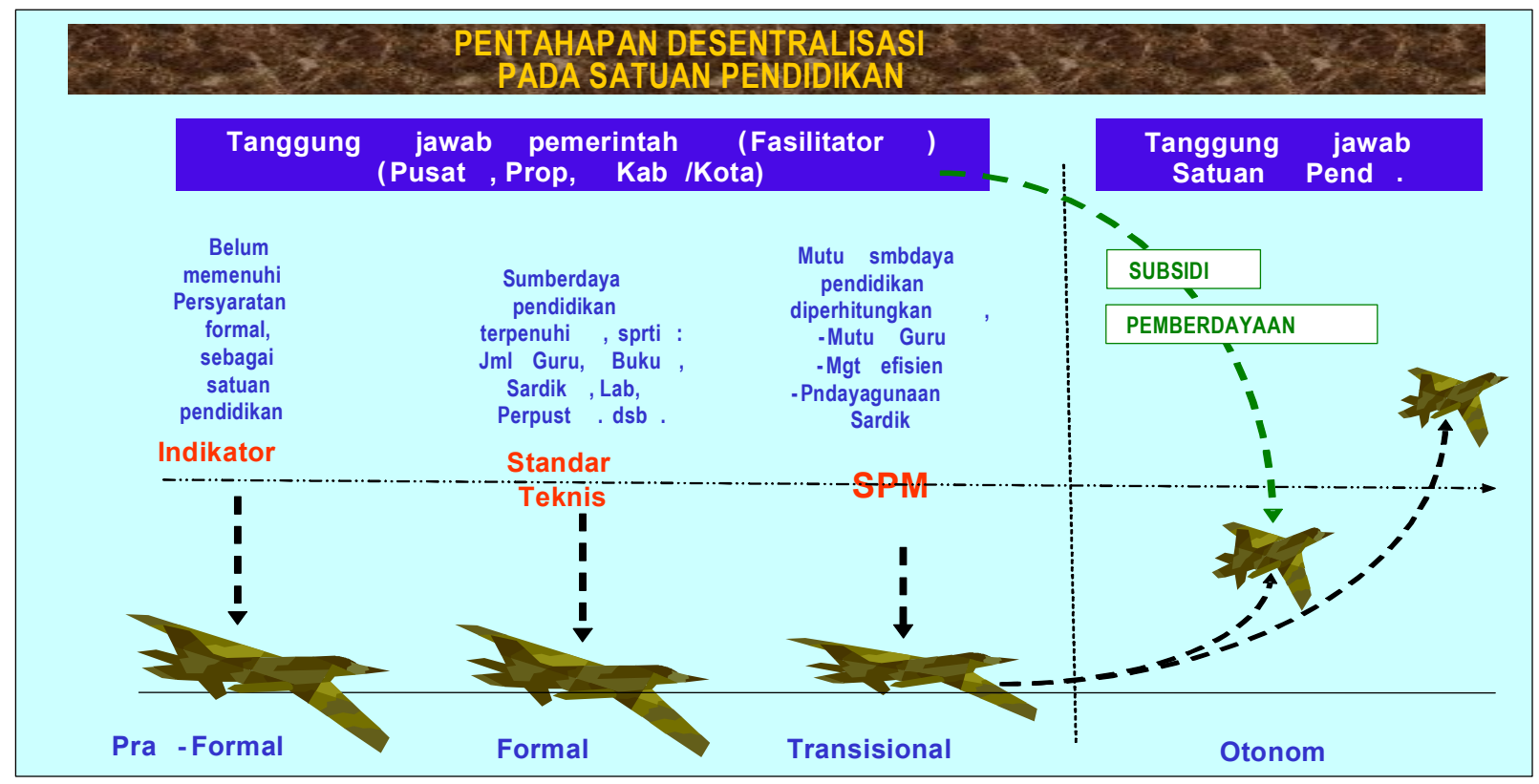

Sumber: UFDP Mendiknas 2004

\section{Gambar 1. Pentahapan Penguatan Kapasitas Desentralisasi Pendidikan Pada Satuan Pendidikan}

meningkatkan perkembangannya pada tahap trnasisi pendidikan. Pada tahap transisional ini diukur dangan menggunakan standar pelayanan minimum tingkat sekolah, terutama yang menyangkut ukuran-ukuran output pendidikan seperti tingkat penurunan putus sekolah, penurunan pengulangan kelas, tingkat kemampuan para siswa, tingkat kelulusan, serta tingkat melanjutkan sekolah pada tingkat yang lebih tinggi. Satuan pendidikan yang sudah mencapai perkembangan ini adalah yang sudah mampu memberikan pelayanan minimal pendidikan yang bermutu, sperti kemampuan memberdayakan sumber-suberdya pendidikan secara optimal, meningkatkan kreatifitas guru, pendayagunaan perpustakaan sekolah secara optimal, kemampuan untuk menambah anggaran dan fasilitas pendidikan dari sumber masyarakat dan kemampuan yang telah terakumulasi ini selanjutnya akan dinaikkan pada tahap pendidikan yang otonom. Pada tahap Otonom, ditandai dengan satuan-satuan pendidikan yang telah mencapai tahap perkembangan diatas, yang merupakan tahap pencapaian capacity building menuju profesionalisasi satuan pendidikan menuju pelayanan pendidikan yang bermutu. Maka jelaslah bagi kita bahwa pada tahap pendidikan yang sudah otonom maka setiap satuan pendidikan sudah mampu memberikan pelayanan diatas SPM sekolah (yaitu Standar Kompetensi Minimum) dan akan bertanggung jawab kepada klien dan stakeholder pendidikan yang terlibat.

Para pemangku kepentingan (stakeholders) mempunyai keharusan memperbaiki pendidikan di Indonesia. Perbaikan pendidikan membutuhkan komitmen dan kesungguhan pemerintah dan masyarakat. Dalam hal ini, komitmen pemerintah dalam pengembangan pendidikan masih jauh dari harapan. Salah satu buktinya adalah alokasi anggaran belanja negara untuk mendanai pendidikan masih di bawah $4 \%$, sementara amandemen UUD 45 mengamanatkan alokasi sebesar $20 \%$ dari APBN. Jika tidak dilakukan usaha-usaha peningkatan pendidikan, maka citacita masyarakat dunia untuk mencapai education for all yang dicanangkan dalam World Education Forum (Konvensi Dakkar, 2000) diperkirakan baru akan tercapai 25 tahun mendatang.

Keberhasilan pembangunan yang berkelanjutan terletak pada kualitas sumberdaya manusia yang unggul. Oleh karena itu, pembangunan manusia harus merupakan ujung tombak strategi pembangunan berkelanjutan. Mengingat kunci pembangunan manusia adalah pendidikan, maka pemerintah harus menempatkan pendidikan sebagai suatu keharusan investasi jangka panjang. Sistem pendidikan perlu dikembangkan agar dapat mencerdaskan 
kehidupan bangsa dan mengembangkan jatidiri, nilai luhur serta budaya bangsa yang produktif. Proses pendidikan perlu dikelola secara sungguhsungguh agar generasi muda lebih bertaqwa, berbudi pekerti luhur, bermartabat, cerdas, ulet, mandiri, demokratis, berkearifan lokal, dan berwawasan global sehingga mampu berperan positif bagi peningkatan kesejahteraan dan keunggulan bangsa.

Apabila anggaran pendidikan yang diusulkan telah terpenuhi baru bisa dirasakan dampak keterkaitan tahapan-tahapan desentraliasi pendidikan, walaupun standar minimum yang diharapkan selama ini masih belum sepenuhnya mengakomodasi kebutuhan-kebutuhan stakeholder dalam bentuk 3P yang membedakan antara pelayanan dengan produk barang yaitu psycal evidence, people dan process dalam salinan surat keputusan namun semuanya itu tergantung pada kebijakan yang akan datang bisa menunjukkan dan menggambarkan proses pendidikaan yang bagaimana cocok untuk kondisi Indonesia dalam rangka efektifitas dan efesiensi pencapaian mutu pendidikan yang diharapkan.

Pendidikan tinggi harus diarahkan untuk meningkatkan daya kerja sehingga mampu menghasilkan ilmu pengetahuan, teknologi, seni dan budaya untuk kemandirian bangsa. Pengembangan unggulan diarahkan pada bidangbidang yang relevan terhadap kepentingan masyarakat dan bangsa, khususnya yang dapat memberikan nilai tambah pada hasil sumberdaya alam secara berkelanjutan serta mengurangi ketergantungan pada pihak luar. Di sisi lain, pemerintah harus mengembangkan sistem yang dapat menjamin kesetaraan akses pada pendidikan yang berkualitas. Lapangan kerja yang terus berubah serta globalisasi mengharuskan penyelenggaraan sistem pendidikan yang mampu mewujudkan masyarakat belajar sepanjang hayat (life-long learning).

Dari uraian diatas, disimpulkan bahwa bila dikaji lebih dalam kaitan SPM dengan mutu dan relevansi pendidikan maka keberhasilan indikator SPM untuk menciptakan mutu pendidikan yang berkualitas tidak terlepas dari proses pembelajaran manajemen berbasis sekolah melalui dewan pendidikan dan komite sekolah.

Mutu dapat diukur dari keterpaduan seberapa efektif pengelolaan sistem pendidikan yang memberikan efek terhadap prestasi belajar secara optimal yang tidak hanya bisa diukur dengan hasil UAN tapi juga output pendidikan secara praktis dan akademis dan profesional. Artinya, relevansi mutu, seberapa jauh hasil-hasil pendidikan dapat disesuaikan dengan kebutuhan masayarakat dalam berbagai bidang misalnya, penghasilan Iulusan, keterampilan Iulusan, pertumbuhan ekonomi, pengurangan pengangguran dan sebagainya bila ingin melihat mutu pendidikan dari fungsi pertumbuhan ekonomi.

Beberapa indikator utama peningkatan mutu pendidikan yang dapat dipantau melalui Standar Teknis dan Standar Minimum antara lain sebagai berikut: 1) Angka Partisipasi Murni anak Usia sekolah yang terserap pada satuan pendidikan; 2) peningkatan prosentase lulusan terhadap jumlah murid tingkat akhir yang mengikuti ujian; 3) pendayagunaan sarana dan prasarana belajar yang lebih optimal di sekolah-sekolah (seperti, buku pelajaran, perpustakaan, alat pelajaran, media pendidikan, pendayagunaan lingkungan sebagai sumber belajar; 4) peningkatan kualitas guru yang diukur dari rerata tingkat pendidikan guru dan jumlah penataran yang diikuti; dan 5) presentase siswa pendidikan pra sekolah terhadap jumlah penduduk usia pra sekolah (SK Mendiknas No. 129a atau No. 135/U/2004) Tentang Standar Pelayanan Minimal Bidang Pendidikan).

\section{Strategik Manajemen untuk Standar Kualitas Pendidikan Masa Depan}

Dengan munculnya kebutuhan akan pendekatan manajemen pendidikan yang melihat-keluar (outward-looking). Sifat melihat-keluar ini diberi tempat yang luas pada era pendekatan kualitatifhumanistik yang bertujuan untuk memanusiakan manusia. Meningkatnya kompetensi mutu yang dimiliki oleh sekolah dan masyarakat berjalan bersamaan dengan meningkatnya intensitas kapasitas dan persaingan. Keberhasilan Pemerintah dalam hal ini dinas pendidikan sangat ditentukan oleh kemampuannya untuk menjadikan sumberdaya pendidikan atau pelayanan pendidikan yang dihasilkan menjadi pilihan siswa, sekolah dan masyarkat, di tengah-tengah perkembangan dan perubahan teknologi informasi yang terjadi saat ini.

Hal inilah merupakan salah satu alasan utama masuknya konsep strategi dalam pemikiran 
manajemen pendidikan untuk pemberdayaan (empowerment) dan membangun kapasitas (capacity building). Isu strategik dalam manajemen pendidikan hampir sama dengan strategik manajerial pada umumnya mencakup seperti penentuan visi dan misi organisasi, identifikasi peluang, mengantisipasi ancaman, menilai kekuatan, menilai kelemahan, penentuan lingkup bidang usaha, pemilihan dan pembentukan keunggulan bersaing, membangun sinergi, menentukan cara-cara tumbuh atau berkembang, membangun kemitraan dan tanggung jawab sosial sebuah institusi pendidikan.

Keaneka-ragaman juga meningkat dengan cepat seperti keaneka-ragaman produk, jasa, wilayah operasi, keaneka-ragaman latar belakang sosio-kultural orang-orang yang bekerja, keaneka-ragaman teknologi, keanekaragaman sosio-kultural wilayah operasi, membawa tantangan baru dalam manajemen pendidikan. Pakar dan praktisi manajemen pendidikan mencari cara untuk dapat melihat unsur-unsur yang beraneka ragam ini sebagai sebuah kesatuan yang utuh atau mencari cara untuk melihat halhal yang dapat menyatukan hal-hal yang beraneka-ragam ini tanpa terjebak dalam keseragaman sebagaimana yang diutarakan oleh Engkoswara Ketua Umum FORMOPPI pada serasehan Pengembangan Karakter Bangsa Berbudaya (2002, 2004a, dan 2004b).

Inilah salah satu alasan yang menyebabkan para ahli manajemen pendidikan di lingkungan LPTK (IKIP) memasukkan konsep atau cara berpikir sistematis dalam pembuatan keputusan pendidikan. Pada awalnya konsep sistem yang dipakai adalah sistem yang sifatnya mekanistik yang menjadi basis dari pendekatan rasionalsaintifik. Namun, kemudian para pemikir dalam manajemen pendidikan merasa perlu memasukkan sistem yang unsur-unsurnya 'lunak' yaitu sistem nilai.

Sistem atau tata-nilai inilah yang menjadi inti dari konsep budaya organisasi pada era sekarang. Keaneka-ragaman juga memunculkan tuntutan baru, yaitu tuntutan untuk menunjukkan keunikan. Agar bisa menjadi pilihan, produk atau jasa atau karakter suatu institusi pendidikan dituntut untuk menunjukkan perbedaannya atau keunikannya yang dapat memberi nilai-lebih di mata masyarakat sebagai pelanggan atau pihak-pihak yang berkepentingan. Persaingan tidak bisa lagi dimenangkan atas dasar melakukan sesuatu lebih baik (do better) tetapi atas dasar melakukan yang berbeda (do differently). Dari sini timbulah tuntutan yang makin kuat untuk berinovasi khususnya dalam bidang pendidikan.

Suatu organisasi atau institusi pendidikan dituntut untuk lebih sering melakukan pembaruan (management change). Pembaruan kurikulum, pembaruan jasa pelayanan, pembaruan sistem, pembaruan cara pendekatan, pembaruan cara berpikir atau pembaruan paradigma. Ini berarti sebuah institusi pendidikan mendapat tekanan yang lebih besar untuk melakukan kreasi atau inovasi secara terus-menerus kalau institusi pendidikan itu ingin tetap hidup dan berkembang. Inovasi yang di masa lalu merupakan kegiatan yang sifatnya sporadik atau periodik, sekarang menjadi kegitatan berkesinambungan. Ini menjadi salah satu pemicu tumbuhnya kebutuhan baru yaitu manajemen inovasi. Inovasi tidak lagi dapat dibiarkan berlangsung secara acak. Maka dalam hal ini institusi pendidikan, dewan pendidikan dan/ atau komite sekolah harus berjalan secara kooperatif apa lagi dalam mengimplemtasikan otonomi pendidikan melalui Manajemen Berbasis Sekolah (MBS) khususnya pada pendidikan dasar dan menengah serta otonomi perguruan tinggi.

Usaha untuk mencari pendekatan atau pengembangan konsep baru dalam manajemen pendidikan juga sangat dipengaruhi oleh cepatnya perkembangan pengetahuan dari segi kehidupan. Dewasa ini pengetahuan menjadi sumberdaya institusi yang utama untuk menciptakan tata nilai. Sampai dengan tahun 1950, modal berarti uang tunai. Para praktisi dan pakar manajemen menyaksikan peran yang sangat besar dari modal yang bersifat maya (virtual) dalam menciptakan kesejahteraan. Modal maya ini mencakup modal intelektual, modal sosial, dan kredibilitas atau modal lunak.

Dalam lingkungan yang sangat cepat berubah, modal maya inipun mengalami keusangan, sebab itu perlu terus-menerus diperbarui. Proses pembaruan ini dilakukan melalui proses belajar dan pembelajaran. Namun demikian, belajar dalam era perkembangan pengetahuan seperti sekarang ini sangatlah berbeda dengan belajar setengah abad yang lalu. Anggota-anggota atau warga suatu institusi pendidikan dituntut untuk dapat belajar bersamasama dengan cepat, dengan mudah, dengan 
gembira, kapan pun dan dimana saja. Hal ini yang menjadi salah satu pendorong dari berkembangnya konsep organisasi belajar (learning organisation). Demikian juga pengetahuan yang melekat pada suatu institusi pendidikan perlu diperbarui, diuji, dimutahirkan, dialihkan, diakumulasikan, agar tetap mempunyai nilai. Hal ini menyebabkan para praktisi dan pakar manajemen mencari pendekatan untuk mengelola pengetahuan yang sekarang dikenal dengan manajemen-pengetahuan.

Di samping perubahan-perubahan yang terjadi di luar organisasi pendidikan yang telah diuraikan di atas, perkembangan cara pendekatan dalam bidang manajemen pendidikan juga dipicu oleh perubahan-perubahan yang terjadi dalam organisai. Di sini akan digaris bawahi perubahan yang berkaitan dengan karakteristik pekerjaan dan orang-orang yang bekerja dalam organisasi pendidikan baik tenaga pendidik maupun pengelola pendidikan yaitu timbulnya kelompok besar pekerja-berpengetahuan (knowledge worker), orang-orang yang bekerja menginginkan self-control daripada dikendalikan orang lain, dan bekerja tidak hanya untuk mencari nafkah namun untuk melakukan sesuatu perwujudan keindahan, ilmu, iman, amaliah yang bermakna (Engkoswara, 2004a).

Lebih jauh lagi, perubahan lingkungan yang sangat cepat menuntut penyesuaian yang lebih sering pada materi pengajaran, silabus, cara kerja, jenis pekerjaan dan kompetensi yang diperlukan. Hal ini telah menyebabkan orang-orang yang bekerja harus siap menghadapi pekerjaanpekerjaan baru yang sama sekali berbeda dengan pekerjaan sebelumnya.

Berbeda dengan pekerja terdahulu yang tingkat pendidikannya relatif lebih rendah yang menerima begitu saja dirinya dikendalikan orang lain, pekerja-berpengetahuan menginginkan kendali yang lebih besar ditangannya sendiri. Mereka lebih menyukai lingkungan kerja dan pekerjaan yang memberikan mereka kebebasan yang lebih besar dalam mengendalikan atau mengarahkan apa yang mereka lakukan. Di masa lalu, pengendalian dilakukan dengan memperbanyak hirakhi dan peraturan. Sekarang, untuk memberi ruang yang lebih luas untuk pengendalian-diri dan pengarahan-diri, institusi pendidikan perlu memperjelas dan membangun visi dan nilai-nilai bersama. Dengan mengacu pada visi dan nilai-nilai bersama ini pengendalian-diri dan pengararahan-diri menjadi ekspresi kebebasan yang bertanggung jawab.

Pekerja-berpengetahuan yang belajar punya kecenderungan yang lebih besar untuk memandang pekerjaan yang mereka lakukan tidak hanya sekedar sebagai kegiatan untuk mencari makan tetapi sebagai kesempatan untuk melakukan sesuatu yang mulia, yang penting dalam hidup ini, yang bermakna. Mereka mencoba mencari atau menemukan tujuan-tujuan yang lebih besar dan lebih luhur dalam melakukan tugasnya dan ingin melihat dan merasakan hasil kerja mereka memberi sumbangan bagi kemajuan dan kesejahteraan masyarakat luas atau kemanusiaan, tidak hanya bagi kemajuan dirinya dan organisasi tempat dia bekerja.

Bagi mereka suatu institusi tidak boleh sekedar menjadi tempat dan kumpulan aktivitas transaksi formal antara orang-orang yang bekerja di dalamnya dengan pemilik atau orang-orang yang mengelolanya, tidak peduli apakah yang drperjual belikan itu tenaga, barang atau pengetahuan. Suatu survai terhadap para lulusan perguruan tinggi di Amerika menunjukkan bahwa uang bukanlah faktor utama dalam tingkat komitmen terhadap pekerjaan. Faktor-faktor yang lebih penting adalah pendidikan untuk kerja dimasa depan dan pemberian tugas-tugas yang memberikan tantangan serta berkolaborasi dengan teman kerja secara sinergi.

\section{Simpulan dan Saran Simpulan}

Pelaksanaan otonomi daerah dan perimbangan keuangan pusat-daerah yang telah diimplementasikan sejak tahun 2001 merupakan momentum yang sangat tepat untuk mereformasi penyelenggaraan pendidikan dari aspek birokrasi, pendanaan, dan manajemen pendidikan. Desentralisasi pendidikan yang efektif tidak hanya melibatkan proses pemberian kewenangan dan pendanaan yang lebih besar dari pemerintah pusat ke pemerintah daerah, tetapi desentralisasi juga harus menyentuh pemberian kewenangan yang lebih besar ke sekolah-sekolah dalam menentukan kebijakan-kebijakan: organisasi dan proses belajar-mengajar, manajemen guru, struktur dan perencanaan di tingkat sekolah, dan sumber-sumber pendanaan sekolah. Hal tersebut didukung oleh Undang-Undang Nomor 20/2003 
tentang Sisdiknas yang dengan tegas memberi kewenangan otonomi pendidikan langsung kepada setiap satuan pendidikan melalui manajemen berbasis sekolah (MBS).

Mutu atau kualitas dan relevansi pendidikan ada pada setiap proses pentahapan di satuan pendidikan. Komitmen Pemerintah untuk berinvestasi pada pendidikan sebagai solusi masa depan bangsa harus segera diwujudkan sepenuhnya melalui pengalokasian 20\% APBN untuk pendidikan di luar anggaran pendidikan kedinasan dan gaji guru. Untuk lebih memperkuat dukungan pengembangan pendidikan, sangat diperlukan kemitraan yang erat antara Pemerintah, pemerintah daerah, dan swasta dalam menyelenggarakan pendidikan yang bermutu. Akses dan ekuitas pada pendidikan yang berkualitas, terutama pendidikan dasar dan menengah, harus terus ditingkatkan. Untuk meningkatkan daya saing bangsa, maka pendidikan unggulan bertaraf internasional perlu dikembangkan, dimonitor, dan dievaluasi secara bertahap dan berkesinambungan di setiap daerah dengan menekankan relevansi dengan kebutuhan, ciri khas daerah/keunggulan lokal serta dapat menampung putra daerah dengan berbagai tingkatan ekonomi (sosial ekonomi status).

Beberapa Bab dan Pasal yang termaktub dalam UUSPN mendapat amanah otonomi dalam penyelenggaraan pendidikan, yaitu: 1) Bab III Pasal 4 tentang Prinsip-prinsip penyelenggaran pendidikan, 2) Bab IV dan Pasal 10 dan Pasal 11 tentang Hak dan kewajiban Pemerintah dan pemerintah daerah, 3) Bab IV Pasal 50 tentang Pengelolaan pendidikan, khususnya pengelolaan satuan pendidikan dasar dan menengah, pendidikan bertaraf internacional dan pendidikan berbasis keunggulan local, maupun pengelolaan pada perguruan tinggi, dan 4) Bab XV tentang Peran serta masyarakat dalam pendidikan (pemberdayaan masyarakat), khususnya terkait dengan penyelenggaraan pendidikan berbasis masyarakat dan peran serta dewan pendidikan dan komite sekolah/madrasah dalam peningkatan mutu pelayanan pendidikan.

\section{Saran}

Mengacu pada simpulan maka disarankan agar Pemerintah Pusat bersinergi dengan pemerintah daerah dan masyarakat (termasuk dunia usaha dan dunia industri) dalam menyelenggarakan program-program pendidikan seperti berikut. Pertama, menetapkan pembangunan manusia melalui pendidikan sebagai strategi pembangunan jangka panjang dengan sasaran pokok pada: (a) menjadikan pembangunan manusia sebagai ujung tombak pembangunan berkelanjutan, (b) menjadikan pendidikan sebagai kunci utama pembangunan manusia, (c) menuntaskan wajib belajar nasional (Wajarnas) 9 tahun dan 12 tahun, (d) meningkatkan komitmen Pemerintah untuk berinvestasi pada pendidikan sebagai solusi masa depan bangsa, dengan segera mewujudkan komitmen anggaran $20 \%$ APBN untuk pendidikan, di luar anggaran pendidikan kedinasan dan gaji guru/PNS. Kedua, meningkatkan sumberdaya pendidikan untuk: a) meningkatkan mutu pendidik dan tenaga kependidikan melalui peningkatan kompetensi, sikap-mental, dan etika profesi; b) meningkatkan mutu dan kompetensi guru serta mutu pendidikan guru; dan c) meningkatkan sarana-prasarana pendidikan. Ketiga, meningkatkan peran masyarakat dalam penyelenggaraan pendidikan dengan berorientasi pada: a) meningkatkan apresiasi masyarakat terhadap pendidikan bermutu dan mengubah orientasi gelar menjadi orientasi kompetensi, kecakapan, kecerdasan dan keluhuran budi; b) meningkatkan apresiasi pada guru dan tenaga pendidik; dan c) melakukan jejaring kerja dan sinergi dengan sekolah kejuruan dalam upaya sinkronisasi penyelarasan pendidikan dengan dunia kerja; Keempat, mengembangkan ilmu pengetahuan, teknologi, seni dan budaya yang membumi dan menjawab kebutuhan masyarakat melalui pendekatan yang memanfaatkan kearifan lokal dan berwawasan global. Kelima, meningkatkan kesejahteraan dan penghargaan kepada tenaga pendidik melalui pendekatan berbasis kinerja. Keenam, meningkatkan kualitas dan efektivitas manajemen pendidikan melalui otonomi penyelenggaraan pendidikan dengan menempatkan Pemerintah sebagai fasilitator, motivator dan pemberdaya. Ketujuh, meningkatkan kualitas dan relevansi pendidikan: a) meningkatkan mutu dan relevansi pendidikan; b) menciptakan sistem pembelajaran yang menyenangkan, kreatif, inovatif, mencerdaskan dan membebaskan; c) mengembangkan sekolah kejuruan dan community college yang sesuai dengan potensi sumberdaya daerah; d) mengembangkan lembaga 
pendidikan unggulan bertaraf internasional dan keunggulan lokal di daerah; e) mengembangkan pendidikan karakter bangsa berdasarkan pada martabat dan komitmen pada nilai-nilai kebangsaan; f) membangun insan yang tekun, teliti, dan optimis. Kedelapan, meningkatkan akses dan equitas memperoleh pendidikan berkualitas serta mengurangi kesenjangan terutama pada pendidikan dasar dan menengah. Kesembilan, mengembangkan sinergitas peran masyarakat dengan mewujudkan kemitraan yang erat antara Pemerintah, pemerintah daerah, dan swasta dalam menyelenggarakan pendidikan yang bermutu. Kesepuluh, melaksanakan layanan pendidikan dengan mengacu pada misi $5 \mathrm{~K}$, yaitu meningkatkan: (i) ketersediaan layanan pendidikan, (ii) keterjangkauan layanan pendidikan, (iii) kualitas/mutu dan relevansi layanan pendidikan, (iv) kesetaraan dalam memperoleh layanan pendidikan, dan (v) kepastian/keterjaminan memperoleh layanan pendidikan. Kesebelas, mengembangkan perguruan tinggi yang berkualitas dan mandiri dengan berorientasi pada: a) menjadikan perguruan tinggi sebagai kekuatan moral dan sumber pemikiran solusi permasalahan bangsa; b) mengembangkan otonomi perguruan tinggi dan mendorong kualitas dan relevansi pendidikan, penelitian dan pengabdian kepada masyarakat; c) mengembangkan sistem pendanaan pendidikan tinggi berbasis kinerja dan berkeadilan/ keberpihakkan; serta d) menjadikan perguruan tinggi sebagai agen pembaharuan melalui hasailhasil research unggulan.

\section{Pustaka Acuan}

Anonim, Paradigma Baru Pendidikan Nasional Dalam Undang-Undang Sisdiknas Nomor 20 Tahun 2003, Bidang Dikbud, KBRI Tokyo.

Ace Suryadi, dan Dasim B., 2004, Pendidikan Nasional Menuju Masyarakat Indonesia Baru. PT Genesindo, Bandung.

Burki, Shahid J., Guillermo E. Perry and William R. Dillinger, 1999, Beyond the Center: Decentralizing the State, The World Bank, Washington, D.C.

Departemen Pendidikan Nasional, 2004, Unit Facilitation Development Project: Bidang Otonomi Pendidikan, Departemen Pendidikan Nasional.

Departemen Pendidikan Nasional, 2003, Undang-Undang Republik Indonesia, Nomor 20 Tahun 2003 Tentang Sistem Pendidikan Nasional, Depdiknas, Jakarta.

Departemen Pendidikan Nasional, 2005, Undang- Undang Republik Indonesia Nomor 14 Tahun 2005 Tentang Guru dan Dosen

Departemen Pendidikan Nasional, 2005, Peraturan Pemerintah Nomor 19 Tahun 2005 Tentang Standar Nasional Pendidikan, Depdiknas, Jakarta.

Departemen Pendidikan Nasional, 2007, Peraturan Pemerintah Nomor 55 Tahun 2007 Tentang Pendidikan Agama dan Pendidikan Keagamaan, Depdiknas, Jakarta.

Departemen Pendidikan Nasional, 2008, Peraturan Pemerintah Republik Indonesia Nomor 47 Tahun 2008 Tentang Wajib Belar, Depdiknas, Jakarta,

Departemen Pendidikan Nasional, 2008, Peraturan Pemerintah Republik Indonesia Nomor 48 Tahun 2008 Tentang Pendanaan, Depdiknas, Jakarta,

Departemen Pendidikan Nasional, 2008. Peraturan Pemerintah Republik Indonesia Nomor 74 Tahun 2008 Tentang Guru.

Departemen Pendidikan Nasional, 2008. Peraturan Pemerintah Republik Indonesia Nomor 37 Tahun 2008 Tentang Dosen.

Departemen Pendidikan Nasional, 2008. Peraturan Pemerintah Republik Indonesia Nomor 41 Tahun 2009 Tentang Tunjangan Guru Besar.

Kementerian Pendidikan Nasional, 2010. Peraturan Pemerintah Republik Indonesia Nomor 17 Tahun 2010 Tentang Pengelolaan dan Penyelenggaraan Pendidikan.

Engkoswara, 2004a. Iman Ilmu Amaliah Indah": Upaya mencegah kerusuhan, korupsi dan disintegrasi bangsa serta bekal manusia hidup di dunia dan di akhirat. Penerbit Yayasan Amal Keluarga, Bandung.

Engkoswara, 2004b. Menuju Indonesia Modern 2020. Penerbit Yayasan Amal Keluarga, Bandung. 
Engkoswara, 2002. Lembaga Pendidikan sebagai Pusat Kebudayaan": Hidup harmoni di keluarga, sekolah dan masyarakat. Penerbit Yayasan Amal Keluarga, Bandung

http://pokguruonline. pendidikan.net. diakses pada tanggal 17 Agustus 2010

Konvensi Dakkar, 2000.

Malik Fajar, 2001, Laporan Menteri Pendidikan Nasional pada Rapat Koordinasi Bidang Kesra Tingkat Menteri, Depdiknas, Jakarta

Patrinos, Harry A. and David L. Ariasingam, 1997, Decentralization of Education: Demand-Side Financing, The World Bank: Directions in Development, Washington, D.C.

Siswo Wiratno, 2009, Kajian Tanggungjawab Negara dalam Mewujudkan Pendidikan Bermutu, Jurnal Pendidikan, Balitbang- Depdiknas, Jakarta.

Siswo Wiratno, 2009. Kajian Proporsi Sekolah Menengah Atas dan Sekolah Menengah Kejuruan Menyongsong Era Globalisasi, Jurnal Pendidikan, Balitbang- Depdiknas, Jakarta.

Sutoro Eko, 2003, Dinamika Desentralisaasi dan Demokrasi Lokal, Makalah dipaparkan dalam Lokakarya"Wawasan Pembangunan Nasional", Yayasan Bina Masyarakat Mandiri (YBM2), Bogor, 17-19 September 2003

Surat Keputusan Menteri Pendidikan Nasional Nomor: 129a atau Nomor. 135/U/2004 Tentang Standar Pelayanan Minimal Bidang Pendidikan.

Undang-Undang Dasar Republik Indonesia Tahun 1945

Undang-Undang Republik Indonesia, Nomor 32 Tahun 2004 Tentang Pemerintahan Daerah(hasil revisi).

Undang-Undang Republik Indonesia, Nomor 33 Tentang Perimbangan Keuangan antara Pemerintah Pusat dan Daerah (hasil revisi).

Undang-Undang Republik Indonesia, Nomor 18 Tahun 1997 Tentang Pajak Daerah dan Retribusi Daerah. 